\title{
МОЖЛИВОСТІ ДЕРМАТОСКОПІЇ В ДІАГНОСТИЦІ АКТИНІЧНОГО КЕРАТОЗУ
}

\author{
○В. С. Глушок' , Т. В. Святенко ${ }^{2}$ \\ Тернопільський обласний клінічний шкірно-венерологічний диспансер ${ }^{1}$ \\ ДЗ "Дніпропетровська медична академія МОЗ України»"
}

PЕЗЮМЕ. Діагностика актинічного кератозу (АК) потребує оптимізації.

Мета - вивчити дерматоскопічні ознаки АК у пацієнтів з різними клінічними формами захворювання, провести аналіз дерматоскопічних зображень.

Матеріал і методи. Ми провели клінічне та дерматоскопічне обстеження пацієнтів з АК, у яких виявили різні дерматоскопічні ознаки на етапі ініціальної оцінки.

Результати. Застосування у практиці і продовження вивчення можливостей дерматоскопії, як сучасного високоінформативного високоспецифічного і чутливого методу неінвазивної діагностики новоутворів шкіри, в тому числі передракових захворювань і АК, допоможе встановлювати клінічний діагноз з високим ступенем достовірності вже на етапі консультування пацієнтів.

КлючОВІ СЛОВА: актинічний кератоз; дерматоскопія; гістологія; плоскоклітинний рак шкіри.

Вступ. Проблема діагностики і раннього виявлення актинічного кератозу (АК) в Україні залишається маловивченою і потребує оптимізації. у світі рівень захворюваності на АК досить високий. Найвищий він у Австралії, де $56 \%$ чоловіків віком 50-59 років і 77 \% віком 60-69 років мають прояви AK [1].

У країнах Європи захворюваність на АК $є$ нижчою, зокрема в Голландії на АК хворіє $27 \%$ осіб віком до 70 років, і $44 \%$ у віковому періоді 70-79 років, у Німеччині - лише 16 \% у 60-70-річному віці $[2,3]$.

Показники захворюваності на АК залежать від географічної широти, в якій проживають люди - чим нижча широта, тобто ближче до екватора, тим вищий рівень захворюваності на АК. Також рівень захворюваності пов'язаний із професійною діяльністю населення. Вища захворюваність у регіонах і країнах, в яких переважна більшість населення зайнята у сільському господарстві, в зв'язку з чим отримує великі дози УФ опромінення впродовж життя, що властиво для нашого регіону і України загалом.

В Україні немає статистичних даних про захворюваність на АК, існують лише поодинокі публікації, що частково висвітлюють проблему діагностики і епідеміології цього захворювання.

АК - хронічне захворювання шкіри, яке характеризується локальною інтраепітеліальною атипією кератиноцитів, локалізується на відкритих до впливу сонця ділянках шкіри, виникає після тривалого або інтенсивного природного чи штучного опромінення УФ у генетично схильних осіб.

Тривають наукові дискусії, щодо того, класифікувати АК до передракових станів шкіри чи вважати раком на місці, оскільки немає достатньо епідеміологічних даних, які 6 дали підставу оцінити частку безпосереднього регресу АК або ж час- тоту прогресування АК в інвазивний ПКРШ. За окремими даними, перехід АК в інвазивну форму раку сягає від 1 до $3 \%$; значно вищим він $\epsilon$ при імуносупресії - до $10 \%$. Значимим $\epsilon$ те, що близько 65 \% первинних ПКРШ та 36 \% базальноклітинних карцином виникли у вогнищах АК [4].

Поширеність і високий рівень захворюваності на AK, асоційованість з ризиком прогресування в інвазивну плоскоклітинну карциному, дані про те, що AK $\epsilon$ прекурсором ПКРШ і маркером немеланомного раку шкіри, на тлі постійного зростання захворюваності на рак шкіри у багатьох країнах, зокрема й в Україні, диктують необхідність покращення діагностики АК.

Мета дослідження - вивчити дерматоскопічні ознаки АК у пацієнтів з різними клінічними формами захворювання, провести аналіз дерматоскопічних зображень.

Матеріал і методи дослідження. Тривалий час діагностика дерматозів, а також новоутворів шкіри, базувалась тільки на даних клінічного обстеження; при необхідності проводили патогістологічні дослідження. Однак клінічне розпізнання не завжди може забезпечити повну верифікацію клінічного діагнозу, тому виникла потреба в інструментальних (апаратних) дослідженнях.

В останні десятиліття широко використовують дерматоскопію - інноваційний спеціальний метод обстеження, за допомогою якого можна удосконалити діагностичний процес при ряді шкірних захворювань. У практиці дерматоонкологів вона вже стала невід'ємною діагностичною процедурою, без якої неможливо провести кваліфіковане консультування пацієнтів з новоутворами шкіри. Тривалість цієї діагностичної процедури, при виконанні досвідченим фахівцем - хвилини, а іноді й секунди. 
Огляди літератури, оригінальні дослідження, погляд на проблему, ювілеї

Чутливість методу дерматоскопії, за даними різних авторів, складає від 89 до $98 \%$, а специфічність 79-98 \% [5].

Термін "дерматоскопія" (dermatoscopy) у 1920 році впровадив німецький вчений Йоган Сафір (Johann Saphier). Прототипом першої дерматоскопії було обстеження бінокулярним мікродерматоскопом із слабим боковим джерелом освітлення у хворих з патологією шкіри. У сучасному вигляді метод застосовують з 1970 p.

Дерматоскопія - неінвазивна діагностична процедура, яка дозволяє швидко in vivo оцінити кольори і мікроструктури епідермісу, дермо-епідермального з'єднання, папілярної дерми, які не видно неозброєним оком. Ці структури специфічно корелюють з гістологічними особливостями.

Цей метод $є$ зручним для лікаря і пацієнта, не має протипоказань.

Інструментом для проведення дерматоскопії $\epsilon$ дерматоскоп - ручний міні-мікроскоп, який складається з лінзи, джерела світла, тримача. Існує три види дерматоскопів: неполяризовані (контактні), поляризовані і гібридні. Обстеження контактним дерматоскопом проводиться з використанням імерсійної олії, яка потрібна як зв'язувальне середовище, для зведення до мінімуму заломлення світла на межі шкіри і повітря. Перевагою поляризаційного дерматоскопа $\epsilon$ можливість безконтактного обстеження, що значно швидше і зручніше у виконанні. Гібридні дерматоскопи мають два режими: поляризаційний і неполяризаційний.

У методиці дерматоскопії використовують оптичне збільшення у 10-16 разів, що дає можливість виявляти ті морфологічні структури, які не видно неозброєним оком: плоске загальне зображення епідермісу і верхнього шару дерми, а також оцінювати особливості цих структур, їх колір. В основі ефекту $є$ принцип відбивання підведеного світла, яке, проникаючи в шари шкіри, відбивається від них під збільшенням, створюючи реальну картину структури пухлини. Це дослідження подібне до огляду під лупою великого збільшення, але різниться значно вищою деталізацією отриманого зображення.

Ми включили цю інформативну і доступну методику у складений нами діагностичний алгоритм АК, керуючись даними літератури про те, що аналіз дерматоскопічної картини, наявність чи відсутність специфічних дерматоскопічних структур, їх локалізація і розподіл дає загальне уявлення про відмінності при різних клінічних варіантах АК, допомагає встановити точний діагноз, проводити диференційну діагностику.

Складений нами діагностичний алгоритм, який $\epsilon$ частиною менеджменту АК на регіональному рівні, включає:
- Виявлення скарг, збір даних анамнезу, захворювання і життя;

- Визначення фототипу шкіри (за класифікацією Фіцпатріка);

- Клінічне обстеження (візуальна оцінка і пальпація вогнищ);

- Проведення диференційної діагностики;

- Проведення дерматоскопії (неполяризаційної і поляризаційної);

- Фотодокументування клінічної і дерматоскопічної картини;

- Гістологічне та імуногістохімічне дослідження у сумнівних випадках.

При обстеженні пацієнтів і встановленні клінічного діагнозу ми користувалися клінічною класифікацією, яка виділяє такі клінічні варіанти АК:

- Еритематозний;

- Запальний;

- Гіпертрофічний;

- Шкірний ріг;

- Актинічний хейліт;

- Пігментований;

- Пігментований, що поширюється;

- Проліферативний;

- АК кон'юнктиви.

При проведенні гістологічних та імуногістохімічних досліджень був встановлений діагноз відповідно до гістологічних варіантів АК.

У розвитку AK за вираженістю клінічних проявів виділяють 3 стадії. Ця клінічна класифікація Olsen ґрунтується на оцінці ураження за товщиною та вираженістю гіперкератозу (ступені 1-3) [6].

У сучасних джерелах літератури описано 4 основні дерматоскопічні ознаки непігментованих варіантів АК: еритему, рожево-червону псевдосітку, тонкі хвилясті судини, мішенеподібні волосяні фолікули; також виділяють 3 ознаки, які характерні для пігментованого АК: виразні фолікули, білі круги, сірі ромбоподібні структури $[5,7,8]$.

Результати вивчення цих дерматоскопічних ознак відображено на рисунках 1-7.

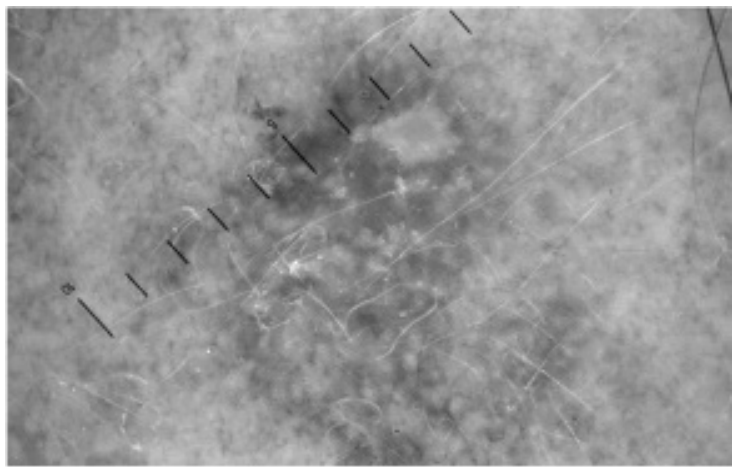

Рис. 1. Еритема, безструктурні світло-червоні гіпопігментовані ділянки. 


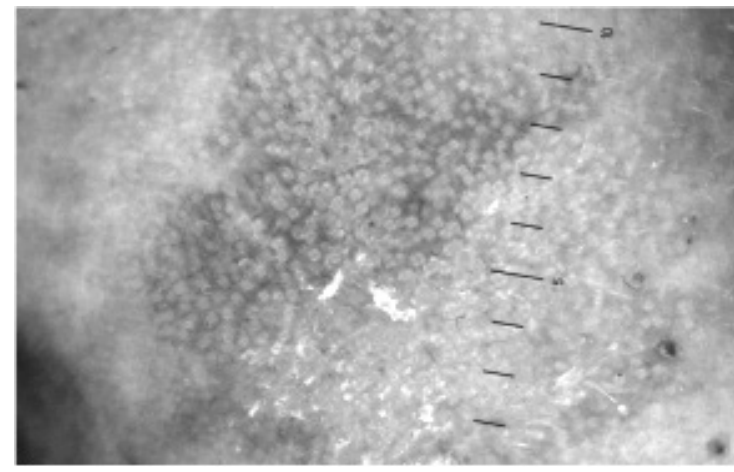

Рис. 2. Рожево-червона псевдосітка, безструктурні червоні ділянки, що нагадують сітку, і маленькі білі ділянки, що відповідають отворам волосяних фолікулів.

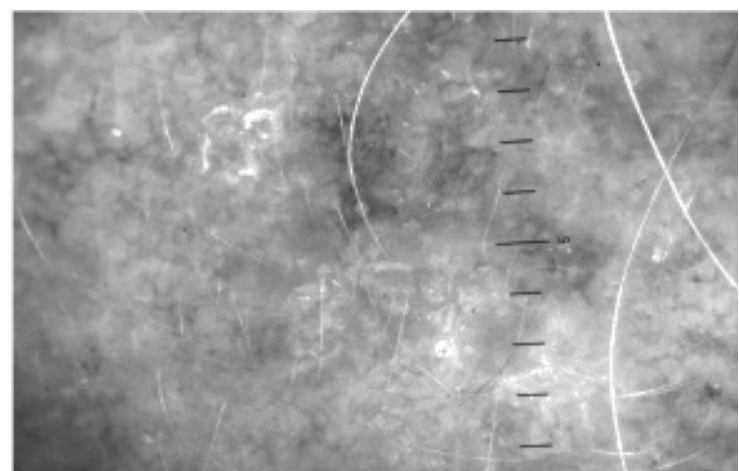

Рис. 3. Тонкі, хвилясті судини, прямі і закручені судини навколо волосяних фолікулів.

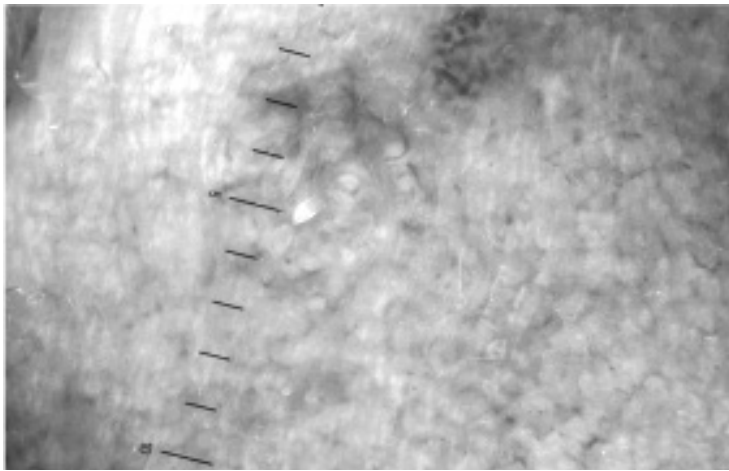

Рис. 4. Мішенеподібні волосяні фолікули, отвори волосяних фолікулів оточені білим кільцем і заповнені жовтуватим кератиновим вмістом.

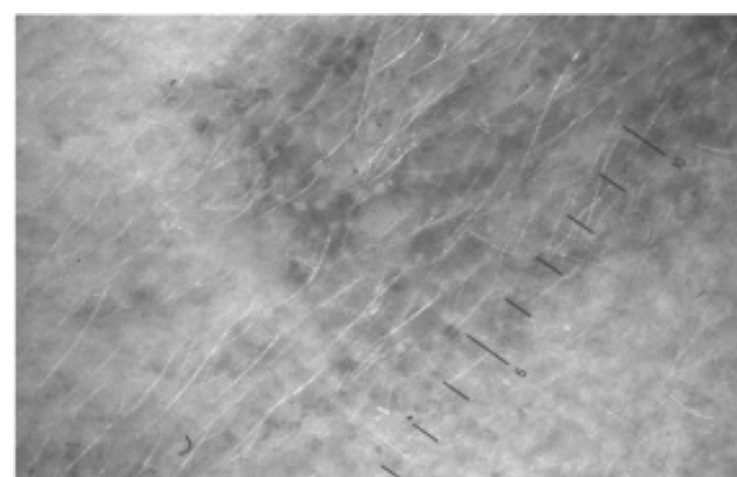

Рис. 5. Виразні фолікули, отвори волосяних фолікулів різних розмірів.

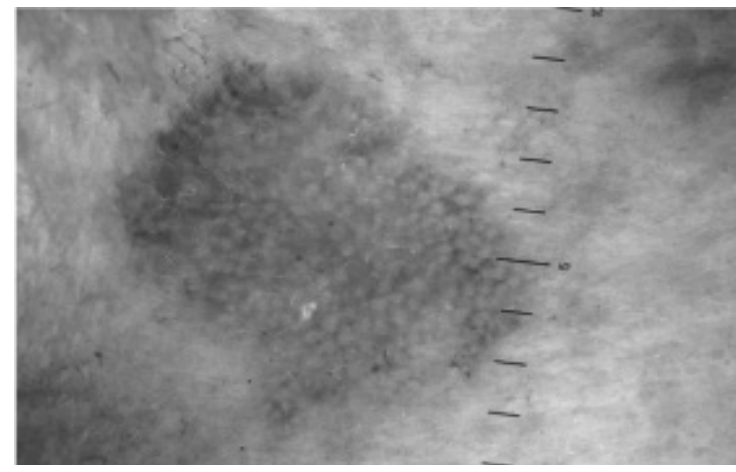

Рис. 6. Білі круги, білі кільцеподібні структури всередині волосяних фолікулів.

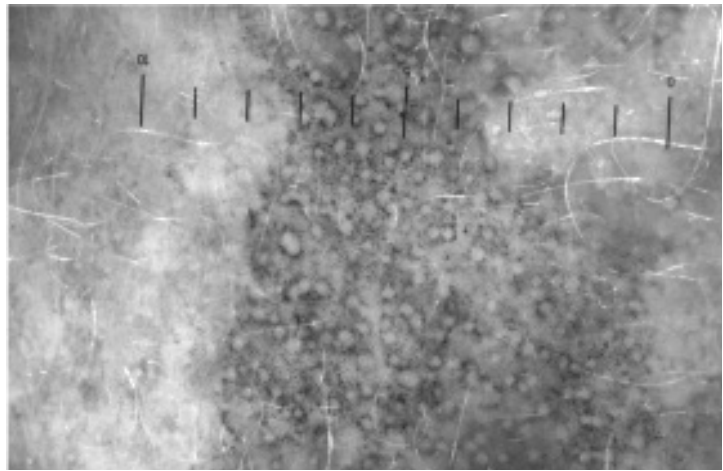

Рис. 7. Сірі ромбоподібні структури, сірі злиті точки, розташовані в лініях, або сіро-коричневі лінійні структури, розташовані між фолікулами.

Дослідження проведені дерматоскопом Heine delta 20T (Німеччина), фотодокументування - приладом Canon 450D (Японія).

За період 2015-2017 рр. проведено 256 дерматоскопій вогнищ у 106 пацієнтів з АК. Частки виявлених дерматоскопічних ознак AK у наших пацієнтів були такі: еритема (68 \%), рожево-червона псевдосітка (53\%), мішенеподібні структури (22 \%), виразні фолікули (35 \%), білі круги (10\%), сірі ромбоподібні структури (5\%).

Наводимо клінічний випадок, у якому в діагностичну програму була включена дерматоскопія.

Пацієнтка К., 74 років, звернулась на амбулаторний прийом в поліклініку із скаргами на наявність утворень на шкірі обличчя, що спричинили їі нерівність, шорсткість, а також на періодичний легкий свербіж в місцях їх локалізації. Вважає себе хворою близько 3 років. Спершу не надавала належної уваги цій проблемі. Вперше звернулась до дерматолога 2 роки тому; використовувала призначену мазь з вмістом кортикостероїду, яку вважає малоефективною, оскільки регресу патологічних змін не відбулося, більше того, з'явилась нова ділянка з подібними проявами.

В анамнезі вказує на тривале перебування на відкритому сонці впродовж життя. Сонцезахисні засоби ніколи не застосовувала. 
Огляди літератури, оригінальні дослідження, погляд на проблему, ювілеї

Локальний статус. Процес локалізується на відкритих ділянках шкірного покриву - на правій щоці і в ділянці правої скроні. У пацієнтки ІІ фототип шкіри за Фіцпатріком. На шкірі вказаної ло- калізації $є$ видимі і пропальповуються папули світло-жовтого кольору, вкриті лусочками сіруватого кольору; вогнище має відносно чіткі межі (рис. 8, 9).

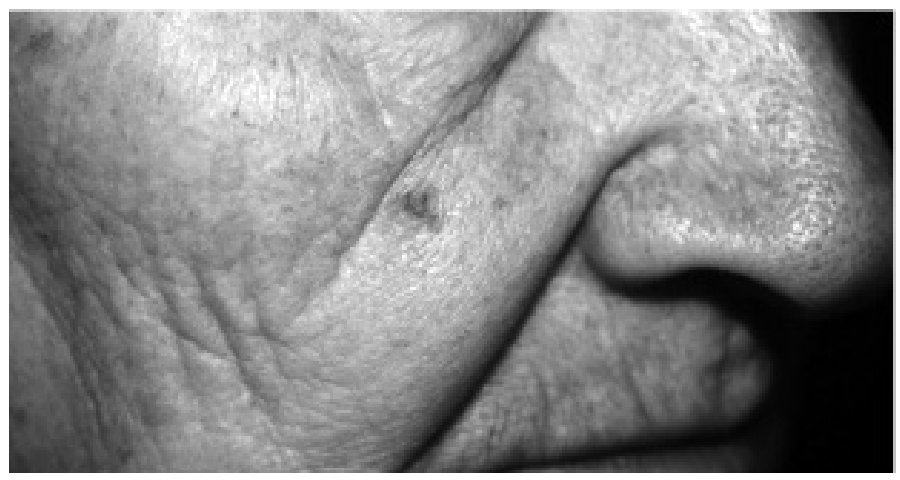

Рис. 8. Утворення на шкірі хворої К, фото.

Клінічна картина відповідає 2 стадії АК. Для підтвердження клінічного діагнозу проведено дерматоскопію, панч-біопсію, а також фотодокументування з метою оцінки динаміки після проведеного лікування.

У результаті дерматоскопії було виявлено біло-рожеві безструктурні ділянки, різних розмірів розширені волосяні фолікули, біло-сірі лусочки.

Результат гістологічного дослідження біоптату, отриманого з правої щоки:

у біоптаті, отриманому з правої щоки, визначається шматочок шкіри, вкритий на деяких ділянках стоншеним, на деяких - потовщеним епідермісом, за рахунок формування брунькоподібних акантотичних тяжів, вираженого гіпер- та паракератозу. В базальному шарі епідермісу виявляються 2-3 шари атипових кератиноцитів, клітини з помірним поліморфізмом, ядра гіперхромні, виявляється невелика кількість мітозів. На інших ділянках в епідермісі визначаються клітини, подібні до койлоцитів. В підлеглій дермі ознаки вираженого солярного еластозу, вогнищева по-

\section{ЛІТЕРАТУРА}

1. Soyer H. P. Actinic Keratosis. Curr. Probl. Dermatol. / H. P. Soyer, T. W. Prow, G. B. E. Jemec. - Basel : Karger, 2015. - P. 1-7.

2. Prevalence of actinic keratosis and its risk factors in the general population: the Rotterdam Study / S. C. Flohil, R. J. van der Leest, E. A. Dowlatshahi [et al.] // J. Invest. Dermatol. - 2013. - No. 133. - P. 1971-1978.

3. Prevalence and risk factors of actinic keratoses in Germany-analysis of multisource data / I. Schaefer, M. Augustin, C. Spehr [et al.] // J. Eur. Acad. Dermatol. Venereol. - 2014. - No. 28. - P. 309-313.

4. Actinic keratoses: natural history and risk of malignant transformation in the Veterans Affairs Topical Tretinoin Chemoprevention / V. D. Criscione, M. A. Weinstock, M. F. Naylor [et al.] // Trial. Cancer. - 2009. - No. 115. P. 2523-2530.

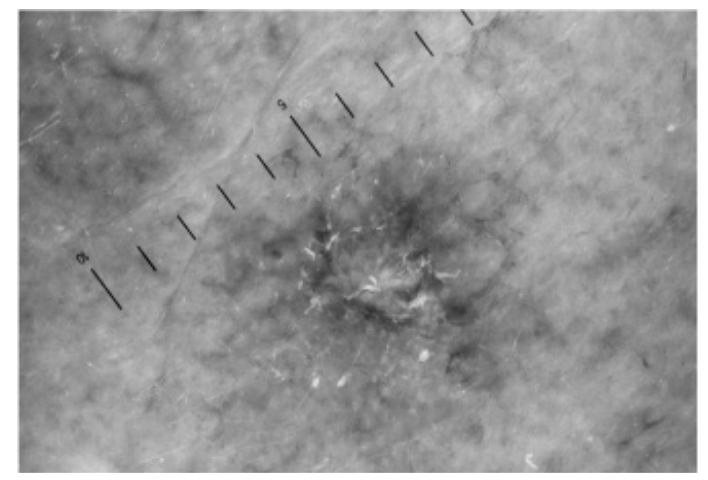

Рис. 9. Дерматоскопічна картина хворої К.

мірна лімфогістіоплазмоцитарна інфільтрація. Морфологічна картина утворення відповідає гіперпластичному варіанту актинічного кератозу.

Діагноз: АК II стадія, гіпертрофічний (гіперпластичний) варіант.

Лікування: проведена кріодеструкція двох вогнищ АК.

Пацієнтці рекомендовано уникати прямого впливу УФ-випромінювання, контролювати час перебування на сонці (оптимально допустимий час - до 11 год. і після 16 год), регулярно застосовувати Ф33 з SPF 50+ і комплекс профілактичних заходів догляду за шкірою.

Висновки. Застосування дерматоскопії і продовження вивчення її можливостей, як сучасного високоінформативного високоспецифічного і чутливого методу неінвазивної діагностики новоутворів шкіри, в тому числі передракових захворювань, і АК зокрема, дасть можливість встановлювати клінічний діагноз з високим ступенем достовірності вже на етапі консультування паці$\epsilon$ нтів.

5. Validation of dermoscopy as a real-time noninvasive diagnostic imaging technique for actinic keratosis / M. Huerta-Brogeras, O. Olmos, J. Borbujo [et al.] // Arch. Dermatol. 2012. - No. 148. - P. 1159-1164.

6. A double-blind, vehicle-controlled study evaluating masoprocol cream in the treatment of actinic keratoses on the head and neck / E. A. Olsen, M. L. Abernethy, C. KulpShorten [et al.] // J. Am. Acad. Dermatol. - 1991. - No. 24. P. 738-743.

7. Dermatoscopy of unpigmented lesions of the skin: a new classification of vessel morphology based on pattern analysis / H. Kittler, E. Riedl, C. Rosendahl, A. Cameron // Dermatopathol. Pract. Conc. - 2008. - No. 14. - P. 4.

8. Dermoscopic features of actinic keratosis and follow up with dermoscopy: A pilot study / J. H. Lee, C. Y. Won, G. M. Kim, S. Y. Kim// J. Dermatol.-2014.-No. 41.-P. 487-493. 
Огляди літератури, оригінальні дослідження, погляд на проблему, ювілеї

\section{REFERENCES}

1. Soyer, H.P., Prow, T.W., \& Jemec, G.B.E. (Eds). (2015). Actinic Keratosis. Curr. Probl. Dermatol. Basel, Karger.

2. Flohil, S.C., van der Leest, R.J., \& Dowlatshahi, E.A. (2013). Prevalence of actinic keratosis and its risk factors in the general population: the Rotterdam Study. J. Invest. Dermatol., 133, 1971-1978.

3. Schaefer, I., Augustin, M., Spehr, C., Reusch, M., \& Kornek, T. (2014). Prevalence and risk factors of actinic keratoses in Germany-analysis of multisource data. J. Eur. Acad. Dermatol. Venereol., 28, 309-313.

4. Criscione, V.D., Weinstock, M.A., \& Naylor, M.F. (2009). Actinic keratoses: natural history and risk of malignant transformation in the Veterans Affairs Topical Tretinoin Chemoprevention Trial. Cancer, 115, 2523-2530.

5. Huerta-Brogeras, M., Olmos, O., \& Borbujo, J. (2012). Validation of dermoscopy as a real-time noninvasive diagnostic imaging technique for actinic keratosis. Arch. Dermatol., 148, 1159-1164.

6. Olsen, E.A., Abernethy, M.L., \& Kulp-Shorten, C. (1991). A double-blind, vehicle-controlled study evaluating masoprocol cream in the treatment of actinic keratoses on the head and neck. J. Am. Acad. Dermatol., 24, 738-743

7. Kittler, H., Riedl, E., Rosendahl, C. \& Cameron, A. (2008). Dermatoscopy of unpigmented lesions of the skin: a new classification of vessel morphology based on pattern analysis. Dermatopathol. Pract. Conc., 14, 4.

8. Lee, J.H., Won, C.Y., Kim, G.M., \& Kim, S.Y. (2014). Dermoscopic features of actinic keratosis and follow up with dermoscopy: A pilot study. J. Dermatol., 41, 487-493. doi:10.1111/1346-8138.12282

\section{ВОЗМОЖНОСТИ ДЕРМАТОСКОПИИ В ДИАГНОСТИКЕ АКТИНИЧЕСКОГО КЕРАТОЗА}

\section{○В. С. Глушок' ${ }^{1}$ Т. В. Святенко}

Тернопольский областной кожно-венерологический диспансер ${ }^{1}$

ГЗ «Днепропетровская медицинская академия МЗ Украины»»

PЕЗЮМЕ. Диагностика актинического кератоза (АК) требует оптимизации.

Цель - изучить дерматоскопические проявления АК у пациентов с разными клиническими формами заболевания, провести анализ дерматоскопических изображений.

Материал и методы. Мы провели клиническое и дерматоскопическое обследование пациентов с АК, которые демонстрировали разные дерматоскопические проявления на этапе инициальной оценки.

Результаты. Использование и продолжение изучения возможностей дерматоскопии, как современного высокоинформативного высокоспецифического и чувствительного метода неинвазивной диагностики новообразований кожи, в том числе предраковых заболеваний, и АК в частности, даст возможность устанавливать клинический диагноз с высокой степенью достоверности уже на этапе консультирования пациентов.

КЛЮЧЕВЫЕ СЛОВА: актинический кератоз; дерматоскопия; гистология; плоскоклеточный рак кожи.

\section{THE OPPORTUNITIES OF DERMOSCOPY IN THE DIAGNOSTICS OF ACTINIC KERATOSIS}

\section{Ternopil Regional Dermatovenerologic Dispensary Dnipropetrovsk Medical Academy²}

SUMMARY. The diagnostics of actinic keratosis needs improvement.

The aim - to learn the dermoscopy signs of actinic keratosis in patients with different clinical forms of the disease, to conduct the analysis of the dermoscopy images.

Material and Methods. We conducted a clinical and dermoscopic examination of patients with AK who presented different dermoscopy signs at initial evaluation.

Results. The use and continued study of the opportunities of dermoscopy as a modern, informative, highly specific and sensitive method of non-invasive skin neoplasms diagnostics, including precancerous diseases and AK in particular, will give the possibility to diagnose with the high degree of reliability even on the patients' counseling stage.

KEY WORDS: actinic keratosis; dermoscopy; histology; squamous cell carcinoma. 